\title{
Nowe możliwości rewitalizacji małych zbiorników wodnych
}

\section{Andrzej Eymontt, Krzysztof Wierzbicki}

\begin{abstract}
STRESZCZENIE
Znaczny postęp technologii wydobywania osadów z dna zbiorników wodnych i przetwarzania ich na wysoko wartościowe nawozy organiczne stworzył nowe możliwości ich rekultywacji.

Te nowe możliwości mogą być dobrze wykorzystane przy aktualizacji Planu Zagospodarowania Przestrzennego Województwa Mazowieckiego, a także przy realizacji zobowiązań Polski wobec Unii Europejskiej w zakresie Ramowej Dyrektywy Wodnej oraz planów odnowy dróg wodnych w Polsce.

Wspomniany postęp manifestuje się możliwością wydobywania osadów dennych o dużej koncentracji składnika stałego (ok. 30\%) pochodzenia organicznego i mineralnego, a więc o małej zawartości wody, która jest następnie sorbowana przez zmikronizowaną biomasę (np. słomę) lub skałę (np. opokę) o właściwościach bakteriobójczych.

Dzięki opracowanej kompleksowej technologii wydobywania, a następnie przetwarzania ww. osadów na kalibrowany nawóz organiczny, stworzone są nowe możliwości podniesienia urodzajności gleb lekkich (ok. 60\% w Polsce), a także zmniejszenia kosztów rewitalizacji małych zbiorników wodnych. Technologia wydobywania osadów została opracowana i wdrożona w Instytucie Technologiczno-Przyrodniczym z siedzibą w Falentach wspólnie z firmą Łukomet, dzięki współfinansowaniu z Europejskiego Funduszu Rozwoju Regionalnego nadzorowanemu przez Mazowiecką Jednostkę Wdrażania Projektów Unijnych.
\end{abstract}

\section{Wprowadzenie}

Rewitalizacja stanowi proces wyprowadzania ze stanu kryzysowego obszarów zdegradowanych, prowadzony w sposób kompleksowy, poprzez zintegrowane działania na rzecz lokalnej społeczności, przestrzeni i gospodarki, skoncentrowane terytorialnie, prowadzone przez interesariuszy rewitalizacji na podstawie gminnego programu [Ustawa o rewitalizacji 2015 r.]. Bardziej szczegółowo problemy prawno-organizacyjne dotyczące rewitalizacji na Mazowszu omówiła P. Sikorska [2016] z pominięciem gospodarki wodnej.

Dotychczas inwestycje związane z rewitalizacją małych zbiorników wodnych wzbudzały powszechną obawę przed koniecznością pokrycia zbyt wysokich kosztów wynikających m.in. z braku odpowiedniej technologii wydobywania osadów dennych i ich racjonalnego zagospodarowania. Tego rodzaju sytuacja odstraszała potencjalnych inwestorów oraz władze samorządów od podjęcia decyzji włączenia do planów gminnych programów rewitalizacji. Aktualizacja Planu Zagospodarowania Przestrzennego Województwa Mazowieckiego zgodnie z uchwałą Sejmiku Województwa Mazowieckiego nr 196/16 z dnia 21 listopada 2016 r., sprzyja podjęciu działań w kierunku omawianej rewitalizacji. Zgodnie z Ustawa o rewitalizacji [2015], a także przy wykorzystaniu Praktycznego komentarza do ww. ustawy [Leszczyński i Kadłubowski 2016].

Tym bardziej, że tego rodzaju działania wynikają ze zobowiązań Polski wobec UE, a konkretnie z transpozycji Ramowej Dyrektywy Wodnej Parlamentu Europejskiego i Rady 2013/39/UE z dnia 12 sierpnia 2013 r., zmieniające dyrektywy 2000/60/WE oraz 2008/105/WE. 
Ta nowa dyrektywa nakłada na Polskę obowiązek wprowadzenia w życie przepisów ustawowych, wykonawczych i administracyjnych niezbędnych do wykonywania dyrektywy od dnia 14 września 2015 r., do 2021 r. oraz uwzględnienia w planach gospodarowania wodami obszarów dorzeczy zaktualizowanych środowiskowych norm jakości, tzw. EQS dla obowiązujących substancji priorytetowych, których liczbę z dotychczasowych 33 powiększono o 15 nowych.

W terminie do 2021 r., powinien być osiągnięty dobry stan chemiczny wód powierzchniowych dla łącznie 45 substancji priorytetowych wymienionych w dyrektywie Parlamentu Europejskiego i Rady 2013/39/UE z 12 sierpnia 2013 r.

Oprócz wyżej wymienionych zobowiązań Polski wobec UE obowiązuje Prawo Wodne z dnia 18 lipca 2001 r. z późn. zm., w którym w art. 2. zapisano wymagania dotyczące zarządzania zasobami wodnymi, a szczególnie w pkt 2. dotyczącym ochrony zasobów wodnych przed zanieczyszczeniami oraz niewłaściwą lub nadmierną eksploatacją oraz w pkt 3. utrzymania lub poprawy stanu ekosystemów wodnych i od wody zależnych.

Organem właściwym w sprawach gospodarowania wodami są m.in. samorządy terytorialne [art. 4. Prawo wodne 2001], a więc kompetentne jednostki do wprowadzenia do Planów Zagospodarowania Przestrzennego m.in. rewitalizacji małych zbiorników wodnych, w celu ich późniejszego wykorzystania na rekreację i kąpieliska [art. 34a Prawa Wodnego].

Istotnym powodem rozpoczęcia inwestycji dotyczących rewitalizacji małych zbiorników wodnych oprócz ww. Dyrektywy i Prawa Wodnego jest dotychczas mała liczba (29) czynnych kąpielisk na Mazowszu. Według danych Urzędu Wojewódzkiego, w 2013 r. na terenie Mazowsza utonęło 90 osób, a do połowy 2014 - 30. Najczęściej wypadki te miały miejsce w nieckach, stawach, wyrobiskach, żwirowniach, rzekach, jeziorach, a szczególnie tam, gdzie brak było ratowników czy też patroli.

Oprócz zagrożeń w postaci utonięcia, Wojewódzki Inspektor Sanitarny na stronie internetowej przypomina, że nie należy korzystać z kąpieli w czasie silnych zakwitów glonów ze względu na możliwość wystąpienia negatywnych skutków zdrowotnych. Bardziej szczegółowe informacje o tych skutkach można uzyskać z wielu publikacji m.in. [Bednarz, Starzecka, Mazurkiewicz-Broń 2002; lub też Siuda i Chróst 2015].

Głównymi przyczynami rozwoju glonów wg M. Kosteckiego [2014] są: sedymentacja części stałych pochodzenia organicznego, mineralnego, wysoki poziom fosforu i innych pierwiastków biogennych, martwe strefy w toni wodnej. Jedynym rozsądnym, trwałym i skutecznym sposobem oczyszczania zbiorników wodnych jest redukcja zarówno azotu i fosforu, względnie całkowite usuniecie osadów.

Brak nadzoru ze strony samorządów nad obszarami wodnymi na Mazowszu oraz rekultywacji zbiorników wodnych stał się przyczyną wielu utonięć, a być może i chorób skóry, które pojawiają się podczas kąpieli w zbiornikach z toksynami wydzielanymi przez sinice.

Przykładem wspomnianego braku nadzoru może być wynik badań odpływu z jednej glinianki na terenie wsi na Mazowszu. Do glinianki tej miejscowa ludność wrzucała różnego rodzaju odpady stałe i płynne, aż z wody pojawiły się tak intensywne odory, że 
Tabela 1. Wyniki badań odpływu z zasypanej glinianki oraz bytowych ścieków surowych z gospodarstwa rolnego

\begin{tabular}{|c|c|c|}
\hline & $\begin{array}{l}\text { Próbka nr } 1 \text { - odcieki } \\
\text { z zasypanej glinianki }\end{array}$ & $\begin{array}{l}\text { Próbka nr } 2 \text { - zakresy stężeń bytowych ścieków } \\
\text { surowych w gminie Sokoły [Zajkowski 2009] }\end{array}$ \\
\hline pH & 7,00 & $7,5 \div 8,0$ \\
\hline $\mathrm{EC} \mu \mathrm{S} / \mathrm{cm}^{3}$ & 4710 & - \\
\hline $\mathrm{BZT}_{5} \mathrm{gO}_{2} / \mathrm{I}$ & 1000 & $100 \div 460$ \\
\hline ChZT mg/l & 1300 & $800 \div 1290$ \\
\hline $\mathrm{N}-\mathrm{NO}_{3} \mathrm{mg} / \mathrm{l}$ & 0,07 & $34 \div 65$ \\
\hline $\mathrm{N}-\mathrm{NH}_{4} \mathrm{mg} / \mathrm{l}$ & 77,66 & $29 \div 100$ \\
\hline $\mathrm{P} \mathrm{PO}_{4} \mathrm{mg} / \mathrm{l}$ & 1,080 & $27 \div 53$ \\
\hline $\mathrm{CL}^{-} \mathrm{mg} / \mathrm{l}$ & 76,8 & - \\
\hline $\mathrm{N} \mathrm{mg/l}$ & 335,3 & - \\
\hline $\mathrm{K} \mathrm{mg/l}$ & 363,3 & - \\
\hline Mg mg/l & 99,7 & - \\
\hline Ca mg/l & 403,3 & - \\
\hline Fe mg/l & 1,39 & - \\
\hline Mn mg/l & 0,93 & - \\
\hline Zn mg/l & 0,19 & - \\
\hline
\end{tabular}

Źródło: badania własne ITP

postanowiono gliniankę zasypać gruntem. Wówczas cześć wody wypłynęła na powierzchnię terenu i dopłynęła do sąsiedniej glinianki z czystą wodą w której były ryby. Pobrane próbki odpływu z zasypanej glinianki zostały poddane analizie, a wyniki zestawiono w tabeli 1. Dla porównania podano również zakresy stężeń bytowych ścieków surowych pobranych z kilku gospodarstw w gminie Sokoły (województwo podlaskie). Analiza i ocena zamieszczonych danych $\mathrm{w}$ tabeli 1 . wskazuje, że $\mathrm{w}$ wodzie $\mathrm{w}$ gliniance stężenie niektórych zanieczyszczeń było większe niż w ściekach bytowych, a unoszone odory były następstwem zanieczyszczeń.

Analizując i oceniając powyżej opisany przypadek z glinianki i brak bezpiecznych kąpielisk postanowiono w Instytucie Technologiczno-Przyrodniczym w Falentach (oddział w Warszawie) podjąć próbę opracowania nowej kompleksowej technologii wydobywania osadów dennych z małych zbiorników wodnych, z zastosowaniem nawożenia, i tym samym przyczynić się do ich rewitalizacji. 


\section{Dotychczasowy stan działań rewitalizacji zbiorników wodnych na Mazowszu}

Stan ten oceniono na podstawie serii wydawniczej TRENDY ROZOWJOWE MAZOWSZA (ISSN 2084-5665) nr 1, 13, 14, wydawanej przez Mazowieckie Biuro Planowania Regionalnego w Warszawie:

- Sałański T. 2012, Zadania do realizacji przez samorzady na Mazowszu, 1;

- Komornicki T. i in., 2012, Zagospodarowanie infrastrukturalne i kapitat fizyczny oraz policentryczność rozwoju Mazowsza, 4;

- Sałański. T. 2014, Potencjały rozwojowe i zarzadzanie strategiczne w gminach Mazowsza. Raport z wyników badania IDI w samorząach gminnych województwa mazowieckiego, 14.

- Stwierdzono zupełne pominięcie w planach samorządów problematyki związanej z działami związanymi z realizacją zobowiązań wobec UE w zakresie dyrektywy Parlamentu Europejskiego i Rady 2013/39/UE z 12 sierpnia 2013 r., a także Prawa Wodnego z 18 lipca 2001 r. (z późn. zm.) oraz poprawy stanu dostępu społeczności szczególnie z obszarów wiejskich do bezpiecznych kąpielisk.

- Uzasadnieniem takiego stanu są olbrzymie potrzeby inwestycyjne w zakresie dróg, kanalizacji, wodociągów, oczyszczalni ścieków, infrastruktury technicznej w szerokim zrozumieniu: szkoły, przedszkola, obiekty sportowe i wiele innych wymienionych w rezultatach badań w 314 gminach, a jednocześnie ograniczone środki finansowe, jakimi dysponują samorządy.

- Czy jednak wobec zagrożeń wynikających z braku bezpiecznych kąpielisk i potrzebą uporządkowania problemów związanych z gospodarką wodną nie warto podjąć tej problematyki przy aktualizacji planów zagospodarowania przestrzennego?

\section{Aktualny stan wiedzy dotyczący stosowanych technologii oraz perspektyw rozwoju rewitalizacji zbiorników wodnych}

Stan ten został szczegółowo opisany m.in. w publikacji [Siuda i Chróst 2015], gdzie wymieniono 16 technologii stosowanych przy rekultywacji zbiorników wodnych podając ich wady, zalety oraz efektywność w procentach wyrażoną stosunkiem korzyści do kosztów. Ponadto stosowane technologie wydobywania osadów dennych sprzętem mechanicznym opisano m.in. w publikacjach [Eymontt i Wierzbicki 2013; Eymontt i Wierzbicki 2015].

Również w źródłach zapisu cyfrowego (internetowych) zamieszczono wiele
Ryc. 1. Zespół roboczy odmularki pobierający osady denne wyposażony w cztery pompy

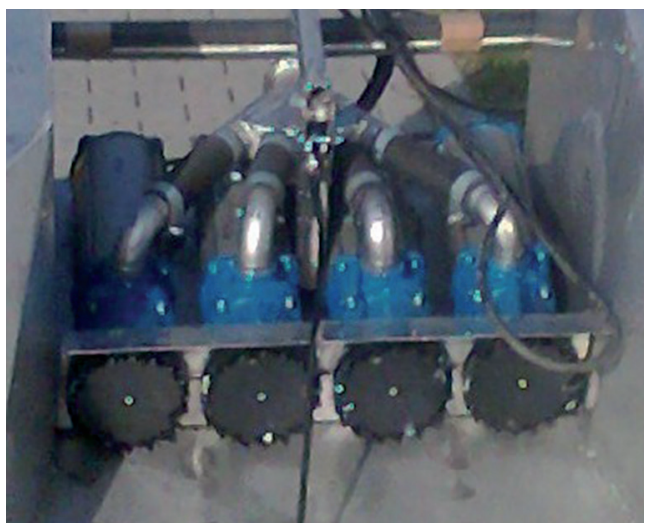


informacji o nowoczesnych metodach oczyszczania i odmulania zbiorników wodnych m.in. przy wykorzystaniu Efektywnych Mikroorganizmów.

Wszystkie metody mają wiele zalet i wad, jednak najpoważniejszą słabością jest brak kompleksowej technologii pozwalającej uzyskać w końcowym efekcie nie tylko efekty środowiskowe, lecz szeroko ujęte gospodarcze, w postaci wytworzenia wysokowartościowych nawozów organicznych, których brak w rolnictwie jest sygnalizowany w postaci zmniejszania się masy organicznej (humusu) w profilu gleby.

Tym też wyróżnia się opracowana metoda w Instytucie Technologiczno-Przyrodniczym w Falentach, dotychczas niestosowana na świecie.

Zespół roboczy odmularki pobierający osady denne porusza się pod wodą i jest wyposażony w 4 wyporowe agregaty pompowe, a jego prędkość jest zsynchronizowana z koncentracją składnika stałego w urobku, oceniana w konsystometrze masowym (ryc. 1). Dzięki temu wykorzystano specyficzne cechy osadów dennych charakteryzujące się właściwościami cieczy plastycznych (nieniutonowskich), których struktura w stanie spoczynku jest sztywna, a po jej zniszczeniu wynikającym z przekroczenia naprężenia ścinającego $\tau_{\mathrm{o}}$ stają się płynne [Stręk 1981]. Tę cechę wykorzystano przy kształtowaniu konstrukcji zespołu pobierającego osady denne, które w początkowej fazie są nagarniane o nienaruszonej strukturze.

Te specyficzne cechy osadów dennych zostały stwierdzone w wielu pracach badawczych m.in. przez W. Parzonkę [1961; 1977], M. Madeyskiego [1999; 2002; 2003 a; 2003 b] oraz F. Stręka [1981], a dla gnojowicy przez K. Wierzbickiego [1982].

Opisana powyżej technologia wydobywania osadów dennych istotnie umożliwia uzyskanie wysokiej koncentracji składnika stałego pochodzenia mineralnego i organicznego, co

\section{Ryc. 2. Wydobyty osad denny o konsystencji zaprawy betonowej}

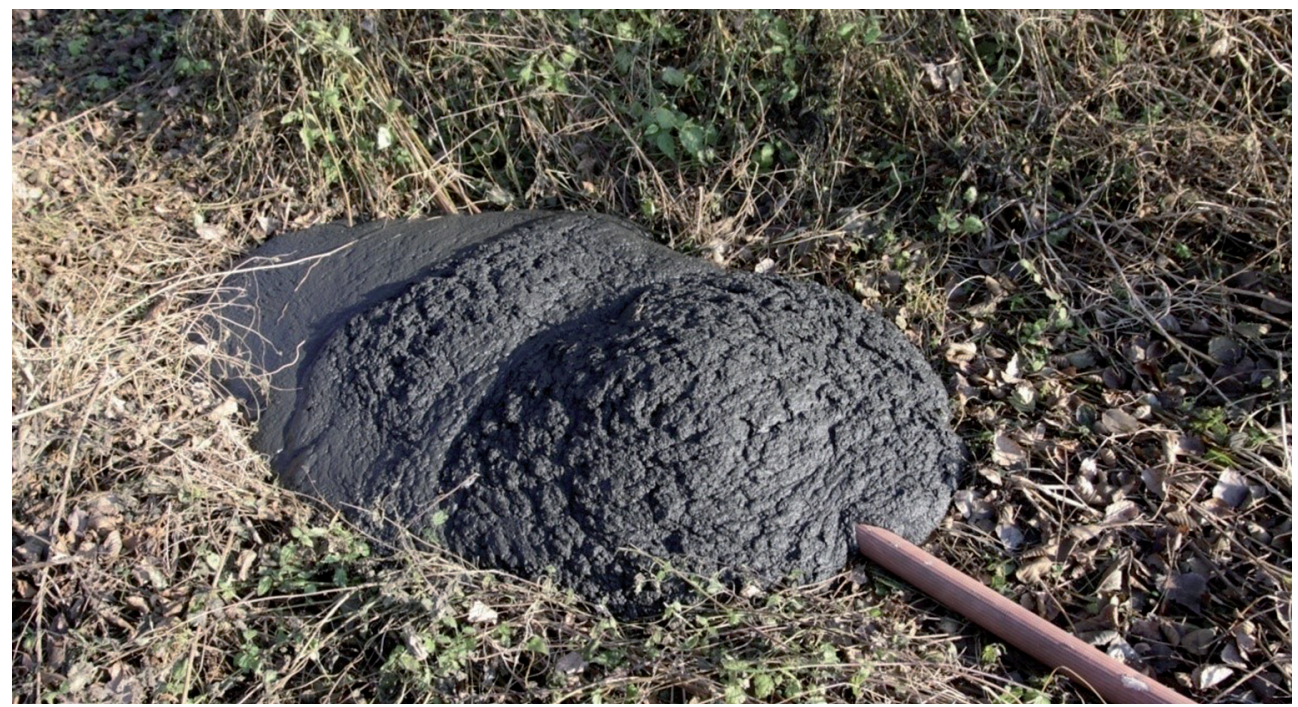


w konsekwencji będzie decydującym czynnikiem wpływającym na efektywność ich wydobycia pod względem kosztów, a następnie przetwarzania na cele nawozu organicznego (ryc. 2).

\section{Możliwości wykorzystania osadów dennych do nawożenia upraw w rolnictwie}

Przy opracowaniu kompleksowej technologii wydobywania osadów dennych istotnym parametrem oprócz ich uwodnienia będą właściwości nawozowe, jeśli końcowym produktem ma być wysokowartościowy nawóz organiczny stosowany w rolnictwie w postaci akceptowanej przez rolników, a więc stałej i o niewielkiej wilgotności.

Stosunkowo mało polskich autorów omawia problemy dotyczące wykorzystania jeziornych i stawowych osadów dennych w rolnictwie do użyźniania gleb. Wyróżnia się tu publikacja B. Gałki i M. Witkowskiego [2010] zwracająca uwagę nie tylko na zawartości poszczególnych nawozowych składników chemicznych i mineralnych w osadach dennych (np. $\mathrm{N}_{\text {org }}$ do $11,34 \mathrm{~g}^{*} \mathrm{~kg}^{-1}$, czy do $C_{\text {org }} 119,5 \mathrm{~g} \mathrm{~kg}^{-1}$ ), ale także na korzystny stosunek C:N wynoszący do 16. Ponadto jeziorne osady denne odznaczają się korzystnym uziarnieniem, odczynem i zawartością substancji organicznej, azotu oraz makroelementów, typowymi dla gleb o wysokiej wartości rolniczej, co predysponuje je do zagospodarowania rolniczego lub rekultywacyjnego. Również zawartość pierwiastków śladowych kwalifikuje badane osady do wykorzystania w rolnictwie.

Właściwości nawozowe osadów dennych omawiają m.in. H. Siwek i M. Włodarczyk [2013] przytaczając szereg argumentów za ich stosowaniem, nawet do nawożenia plantacji warzyw czy też kukurydzy. Osady denne pochodzące ze stawów rybnych, odznaczając się wysoką zawartością azotu (C:N > 12), stanowiły wartościowy składnik gleb przy produkcji ryżu.

Wśród autorów publikacji dotyczących osadów dennych ze stawów rybnych wyróżniają się opracowania M. Madeyskiego [1999; 2002; 2003 a, 2003 b; 2003 c] oraz T. Bednarczyka i M. Madeyskiego [1990; 1992; 2002]. Prace te jednak tylko w sposób ogólny podkreślają przydatność ww. osadów na potrzeby nawożenia w rolnictwie. Natomiast w sposób szczegółowy opisują m.in. procesy gromadzenia się osadów na dnie stawów (sedymentacja), a także ich charakterystyki reologiczne, co jest istotną informacją do oceny możliwości transportu hydraulicznego.

W celu ustalenia wartości nawozowych osadów dennych ze stawów rybnych pobrano sondą (konstrukcji ITP) próbki z warstwy o miąższości ok. $10 \mathrm{~cm}$ ze stawów w Falentach. Miejsca poboru prób wybrano w pobliżu łowisk. Ocenę uziarnienia, jak i pozostałych parametrów wykonano metodami opisywanymi przez Z. Brogowskiego i Z. Czerwińskiego [1986], a mianowicie areometryczną Casagrande’a w modyfikacji Prószyńskiego stosując do peptyzacji pirofosforan sodu i mieszając mieszadłem wirnikowym zamiast gotowania. Skład chemiczny oznaczono metodą AAS, po uprzedniej ekstrakcji próbek osadu stężonym kwasem nadchlorowym. Materię organiczną oznaczono metodą Tiurina.

W celu oceny struktury badanych próbek osadów, w Ogólnouczelnianym Centrum Analitycznym SGGW wykonano zdjęcia skaningowym mikroskopem elektronowym, przy powiększeniu od 400 do 20000 krotnym. 
Badania mikroskopowe szeregu prób wykazują brak ziaren piaskowych zbudowanych z kwarcu. Są to konglomeraty powstałe w wyniku zlepów drobnych ziaren, szkielecików okrzemek i innych organizmów w tym ryb. Konglomeraty te są bardzo silnie spojone tworząc ziarna o zróżnicowanej średnicy, niepoddające się rozpadowi podczas peptyzacji. Uziarnienie badanych osadów stanowi sztuczny, wtórny twór uformowany przez wielolecia zalegania na dnie. Materiał ten może być wykorzystany w rolnictwie, jako ulepszacz gleb pod względem fizycznym i fizykochemicznym. W glebie frakcja piaskowa przekształci się bowiem stopniowo we frakcję $<0,02 \mathrm{~mm}$, w tym ilastą $<0,002 \mathrm{~mm}$.

Spora zawartość szkieletów obumarłych okrzemek, składających się z $\mathrm{SiO}_{2}$ ma ogromne znaczenie nawozowe. Krzemionka jest jednym z ważnych składników roślin warzywnych i zbożowych. Składnik ten jest mało doceniany w polskim rolnictwie i nie jest badany przez specjalistów od nawożenia.

Skład chemiczny badanych osadów dennych ze stawów wykazuje wyraźne zróżnicowanie ilościowe składników w poszczególnych stawach, jak i w warstwach pobranych osadów o grubości ok. 0-5 i 5-10 cm (tabela 2).

Istotnym składnikiem w osadach dennych jest azot. Jego zawartości w poszczególnych stawach i warstwach wahają się od 1,08 do 7,03 $\mathrm{g}^{*} \mathrm{~kg}^{-1} \mathrm{Osadu}$. Stanowi to przy wniesieniu 20 t*ha $^{-1}$ od 22 do $140 \mathrm{~kg} \mathrm{~N}^{*} \mathrm{ha}^{-1}$.

Szereg malejącego udziału poszczególnych badanych składników jest następujący:

$$
\mathrm{N}>\mathrm{Mg}>\mathrm{K}>\mathrm{P}>\mathrm{Na}
$$

Ten szereg składników mineralnych występuje w badanych próbkach z czterech stawów na obszarze Falent (tabela 2). Osady denne z badanych stawów mogą zatem stanowić jeden z cenniejszych materiałów nawozowych wzbogacających gleby w mineralne makroelementy o ustabilizowanym stanie związków organicznych, które w glebach uprawnych ubywają w sposób nieprzewidywalny.

Mikroelementy (Fe, Mn, Zn, Cu, Pb) w badanych osadach dennych były w niewielkim stopniu zróżnicowane pod względem ilościowym. Głównym składnikiem było żelazo, a najmniejszą zawartość stanowiła miedź. Ilościowo metale ciężkie w omawianych osadach można uszeregować według malejącej ich zawartości następująco:

$$
\mathrm{Fe}>\mathrm{Mn}>\mathrm{Zn}>\mathrm{Pb}>\mathrm{Cu}
$$

Przyjmując cały zapas tych metali, ze wszystkich badanych stawów według uśrednionych danych za $100 \%$, to procentowy szereg może być następujący:

$$
83,3>13,2>2,1>0,8>0,6 \% \text {. }
$$

Należy podkreślić, że zbadane osady denne stawów nie wykazują zawartości metali ciężkich przekraczających normy ilościowe przewidziane w Rozporządzeniu Ministra Środowiska z dnia 16 kwietnia 2002 r. Osady te można wykorzystywać w szeroko pojętym rolnictwie. Pod względem zawartości metali ciężkich stanowią nawóz równorzędnie wartościowy jak obornik bydlęcy. Dawka 20 do 30 tha $^{-1}$ w zależności od klasy bonitacyjnej gleb zabezpieczy 
Tabela 2. Zawartość niektórych składników w osadach dennych stawów w Falentach i Raszynie

\begin{tabular}{|c|c|c|c|c|c|c|c|c|}
\hline \multirow[b]{2}{*}{$\begin{array}{l}\text { Miąższość warstwy } \\
\text { osadu w }[\mathrm{cm}]\end{array}$} & \multicolumn{2}{|c|}{ Staw Spiski } & \multicolumn{2}{|c|}{ Staw nr 13} & \multicolumn{2}{|c|}{ Staw Parkowy 2} & \multicolumn{2}{|c|}{$\begin{array}{c}\text { Staw } \\
\text { Puchalskiego }\end{array}$} \\
\hline & $0-5$ & $5-10$ & $0-5$ & $5-10$ & $0-5$ & $5-10$ & $0-5$ & $5-10$ \\
\hline$M g$ w $\left[g^{*} \mathbf{k g}^{-1}\right]$ & 0,80 & 0,62 & 1,02 & 0,70 & 1,07 & 1,21 & 2,24 & 2,93 \\
\hline$K w\left[g^{*} \mathbf{k g}^{-1}\right]$ & 0,75 & 0,62 & 0,88 & 0,75 & 0,96 & 1,82 & 1,93 & 2,25 \\
\hline $\mathrm{Na} w\left[g^{*} \mathbf{k g}^{-1}\right]$ & 0,06 & 0,05 & 0,07 & 0,06 & 0,08 & 0,10 & 0,14 & 0,17 \\
\hline $\mathbf{P} w\left[g^{*} \mathbf{k g}^{-1}\right]$ & 0,22 & 0,37 & 1,77 & 1,75 & 0,50 & 0,22 & 1,63 & 2,07 \\
\hline $\mathbf{N} w\left[\mathbf{g}^{*} \mathbf{k g}^{-1}\right]$ & 1,61 & 1,08 & 2,08 & 1,78 & 3,45 & 1,20 & 6,32 & 7,03 \\
\hline suma & 3,44 & 2,74 & 5,82 & 5,04 & 6,06 & 4,55 & 12,26 & 14,45 \\
\hline C w $\left[g^{*} \mathbf{k g}^{-1}\right]$ & 22,1 & 26,0 & 32,7 & 36,5 & 56,7 & 18,3 & 87,1 & 92,3 \\
\hline C:N w [ $\left.\mathbf{g}^{*} \mathbf{k g}^{-1}\right]$ & 13,7 & 24,0 & 15,7 & 20,5 & 16,4 & 15,2 & 13,8 & 13,1 \\
\hline Fe w $\left[\mathbf{m g}^{*} \mathbf{k g}^{-1}\right]$ & 445 & 386 & 1443 & 1125 & 809 & 1080 & 1911 & 2507 \\
\hline Mn w [mg*kg $\left.\mathbf{k g}^{-1}\right]$ & 50,2 & 45,4 & 291,9 & 229,7 & 170,0 & 97,3 & 313,5 & 341,0 \\
\hline $\mathrm{Zn} \mathrm{w}\left[\mathbf{m g}^{*} \mathbf{k g}^{-1}\right]$ & 14,4 & 11,8 & 21,1 & 16,7 & 36,7 & 30,6 & 50,9 & 60,5 \\
\hline Cu w $\left[\mathbf{m g}^{*} \mathbf{k g}^{-1}\right]$ & 4,9 & 4,9 & 8,1 & 7,0 & 8,5 & 7,2 & 13,0 & 14,1 \\
\hline $\mathrm{Pb}$ w [mg* $\left.\mathbf{k g}^{-1}\right]$ & 16,2 & 13,2 & 9,4 & 8,0 & 7,7 & 13,4 & 15,8 & 11,6 \\
\hline
\end{tabular}

Źródło: A. Eymontt i in. 2017

uprawiane rośliny w pełny zapas składników biogennych. W glebach o niskiej klasie bonitacyjnej IVa, V i VI byłby wskazany niewielki dodatek fosforu i potasu w dawkach uzależnionych od uprawianej rośliny.

Wykorzystanie zawartych składników nawozowych w osadach dennych będzie bardziej racjonalne jeśli są one wydobywane o wysokiej koncentracji składnika stałego pochodzenia organicznego i mineralnego, co nie będzie wymagało stosowania dodatkowych komponentów pochłaniających wodę.

Wobec powyższego ważnym ogniwem opisywanej technologii jest urządzenie do mieszania wydobytych osadów dennych z komponentami zapewniającymi wymagany skład nawozowy, bądź pochłanianie wody w celu uzyskania konsystencji nadającej się do aplikacji do gleby typowymi maszynami (rozrzutnik obornika itp.). W tym celu przeprowadzono doświadczenie [Strzelczyk i Rossa 2016] polegające na zmieszaniu 3,8 kg osadu dennego zawartości suchej masy 25\% z 0,31 kg mikronizowanej słomy o wielkości cząstek powyżej 100 mm w celu sorpcji wody i uzyskania gęstości porównywalnej z obornikiem. Badania 
Tabela 3. Udział w procentach składników mieszaniny osadu dennego z mikronizowaną słomą

\begin{tabular}{|l|c|c|c|c|c|}
\hline & N & P & C & S & H \\
\hline Słoma + osad & 0,66 & 0,13 & 12,02 & 0,29 & 1,10 \\
\hline
\end{tabular}

Źródło: M. Strzelczyk i L. Rossa 2016

podstawowych składników mieszaniny wykonano metodą analizy elementarnej, a wyniki zestawiono w tabeli 3.

Następnie w laboratorium Instytutu przeprowadzono wstępne badania wazonowe (w czterech powtórzeniach bez oceny statystycznej), wartości nawozowej mieszanin osadów dennych ze słomą w kilku wariantach, przyjmując dawkę nawozu nieprzekraczająca $170 \mathrm{kgN}^{*} \mathrm{ha}^{-1}$. Użyto mieszanki następujących traw gazonowych - kostrzewa czerwona (festuca rubra), kostrzewa trzcinowata (festuca arundinacea), życica trwała (lolium perenne), życica wielokwiatowa / rajgras włoski (lolium multiflorum), życica westerwoldzka / rajgras holenderski (lolium westerwoldicum).

Zastosowano kombinacje:

1. ZERO - gleba

2. D - gleba i osady denne ze stawów rybnych

3. D+M - gleba, osady denne ze stawów rybnych i słoma mikronizowana (rozdrobniona do wielkości cząstek poniżej 0,01 mm)

4. D+M+S - gleba, osady denne ze stawów rybnych, słoma mikronizowana i sieczka.

Wyniki badania masy roślin traw metodą wagową przedstawiono na rycinie 3., a procentowy udział podstawowych składników pokarmowych w mieszaninach nawozowych i glebie (określony metodami kolorymetryczną i ASA po mineralizacji) w tabeli 4.

Tabela 4. Zawartość w (\% s.m) składników pokarmowych w mieszaninach nawozowych przed i po doświadczeniu nawozowym

\begin{tabular}{|l|r|r|r|c|c|c|}
\hline \multirow{2}{*}{ Gleba i mieszaniny nawozowe } & \multicolumn{2}{|c|}{ Przed nasadzeniem traw } & \multicolumn{3}{c|}{ Po ścięciu traw } \\
\cline { 2 - 7 } & N & \multicolumn{1}{c|}{ P } & K & N & P & K \\
\hline Gleba & 0,093 & 0,047 & 0,077 & 0,061 & 0,039 & 0,072 \\
\hline Gleba+osad denny & 0,109 & 0,05 & 0,091 & 0,080 & 0,044 & 0,069 \\
\hline Gleba+osad denny+mikronizat & 0,113 & 0,055 & 0,099 & 0,071 & 0,043 & 0,077 \\
\hline Gleba +osad denny+mikronizat+słoma cięta & 0,099 & 0,047 & 0,085 & 0,065 & 0,041 & 0,082 \\
\hline
\end{tabular}

Źródło: M. Strzelczyk i L. Rossa 2016 


\section{Ryc. 3. Średnia masa traw zebranych z czterech wazonów do kolejnych kombinacji}

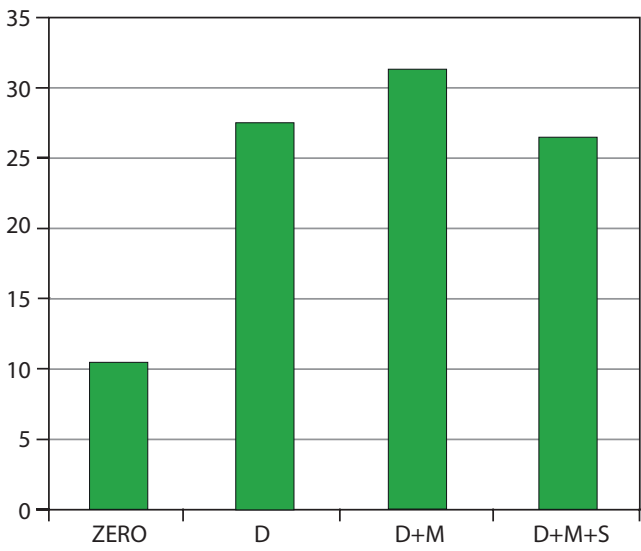

średnia świeża masa [g]

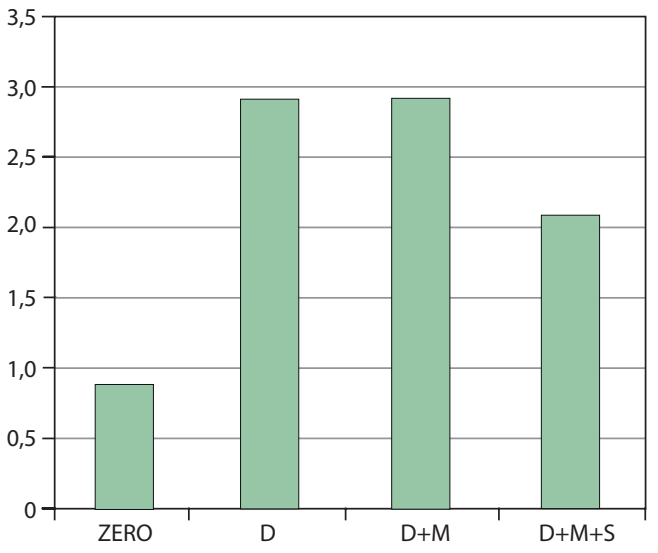

średnia sucha masa [g]

Źródło: M. Strzelczyk i L. Rossa 2016

Pomimo, iż osady denne zawierają stosunkowo mniej związków węgla i azotu w stosunku do innych organicznych substancji półpłynnych, takich jak np. gnojówka, dodanie ich jako nawozu powoduje znaczny wzrost masy zebranych roślin. Dodatek zmikronizowanej słomy zwiększa jeszcze otrzymany plon, w przeciwieństwie do dodatku sieczki słomy. W wazonach z mieszaniną osadów dennych ze słomą mikronizowaną nastąpiło największe zmniejszenie zawartości składników pokarmowych, co zdaje się potwierdzać pozytywną rolę mikronizatu w ich uwalnianiu.

W zależności od przyjętej technologii rozprowadzania wydobytego urobku, bez zmieszania z innymi komponentami, jako nawozu organicznego po powierzchni gleby lub pod jej powierzchnią możemy uzyskać znaczne korzyści w przyroście plonów. Jest to najprostszy sposób rolniczego wykorzystania wydobytych osadów dennych.

\section{Opis funkcjonowania odmularki spełniający wymagania nowej technologii}

Podstawowy zespół roboczy odmularki przemieszcza się pod powierzchnią wody przy minimalizacji zmącenia wody podczas wydobywania osadów dennych, zapewniając maksymalizację zawartości części stałych pochodzenia organicznego i mineralnego (ryc. 1). W opracowanej dotychczas odmularce jej przemieszczanie jest realizowane za pośrednictwem liny nawijanej na wciągarkę napędzaną z układu hydrauliki ciągnika. Zainstalowane na ww. zespole agregaty pompowe zapewniają transport hydrauliczny wydobytego urobku 


\section{Ryc. 4. Schemat przeciągania liną odmularki po dnie zbiornika wodnego za pośrednictwem wciągarki zainstalowanej na wysięgniku mocowanym do ciągnika}

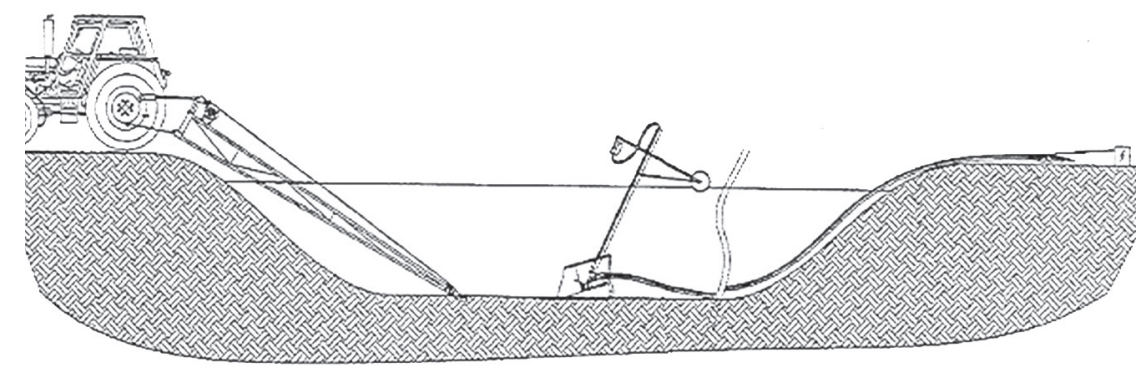

na odległość od 300 do 1000 m. Odległość transportu hydraulicznego uzależniona jest od specyficznych właściwości osadów dennych oraz geometrycznej wysokości tłoczenia uzależnionej od topografii terenu. Takie funkcjonowanie odmularki stało się możliwe dzięki nadaniu odpowiednich kształtów zespołowi roboczemu pobierającemu osady denne.

Na wałach agregatów pomp wyporowych zainstalowane są rozdrabniarki części stałych zawartych w osadach dennych, a następnie są one tłoczone pompami z jednozwojowym rotorem umieszczonym $\mathrm{w}$ elastycznym dwuzwojowym statorze zaciskanym na rotorze w zależności od panującego ciśnienia w komorze po stronie łłocznej. Dzięki zastosowaniu tego typu agregatów pompowych znacznie zwiększyła się ich trwałość. Jednocześnie transport hydrauliczny ujednorodnionej mieszaniny ulega tzw. uproszczeniu struktury cieczy [Parzonka 1977], co umożliwia jej dalszy transport hydrauliczny dzięki zmniejszeniu oporów przepływu [Wierzbicki 1982].

Najprostszym sposobem przemieszczania odmularki po dnie zbiornika wodnego jest przeciąganie jej lina, co schematycznie ilustruje rycina 4 .

Zasilanie w energię elektryczną odmularki może być realizowane przewodem z generatora prądu umieszczonego na przeciwległym brzegu lub też ze spalinowego agregatu prądotwórczego umieszczonego ponad zespołem roboczym, i mocowanym do konstrukcji wspornej łączącej pływaki. Do ww. konstrukcji mocowane są dwie ręcznie napędzane wciągarki linowe umożliwiające opuszczanie względem poziomu wody zespołu roboczego na dno zbiornika.

Transport odmularki na miejsce przeznaczenia może być zrealizowany na przyczepie mocowanej do samochodu.

Prototyp opisanej odmularki zbudowała firma Łukomet - Krzysztof Łuszczyk przy współpracy z Instytutem Technologiczno-Przyrodniczym dzięki współfinansowaniu z Europejskiego Funduszu Rozwoju Regionalnego w ramach osi priorytetowej Wykorzystanie działalności badawczo-rozwojowej w gospodarce, działanie 1.2 Działalność badawczo-rozwojowa przedsiębiorstw, nadzorowanej przez Mazowiecką Jednostkę Wdrażania Projektów Unijnych. 


\section{Wstępna ocena ekonomiczna opisanej technologii}

Przy założeniu 8 godzin czasu pracy w ciągu doby, a w tym efektywnej pracy odmularki trwającej 5 godzin oraz wydajności w granicach od $0,0012 \mathrm{~m}^{3} / \mathrm{s}$ do $0,0032 \mathrm{~m}^{3} / \mathrm{s}$, uzyskamy urobek o konsystencji płynnej, półpłynnej lub plastycznej o objętości od 21,6 $\mathrm{m}^{3}$ do 57,6 m³. Po dodaniu zmikronizowanej słomy otrzymamy nawóz o konsystencji np. przypominającej obornik, zarazem o równoważnej wartości nawozowej. Cena rynkowa tego typu nawozów z dostawą (według Google „nawozy organiczne”) wynosi od 2,0 zł/dm³ do 1,5 zł/dm³. Pomijając wzrost objętości wydobytego osadu dennego w wyniku dodania zmikronizowanej słomy oraz kosztu jej zakupu, a także koszty związane z wydobyciem osadów dennych, to teoretyczna maksymalna wartość otrzymanego nawozu zawiera się w granicach od 32400 43200 zł oraz do 86400 - 115200 zł w ciągu 5 godzin pracy odmularki.

Przyjmując potencjalnie wartość uzyskaną ze sprzedaży wydobytego i spreparowanego nawozu wieloskładnikowego wynoszącą tylko $2 \%$ od ww. cen zakupu oferowanych w handlu, otrzymamy możliwość uzyskania dochodu w granicach od 648 do 864 zł oraz od 1728 do 2304 zł w zależności od wydajności odmularki w ciągu 5 godzin zmiany w ciągu doby. W powyższych obliczeniach pominięto cenę zmikronizowanej słomy, obniżając zysk o 98\%.

Zakładając możliwość pracy odmularki przez 20 dni w ciągu miesiąca, a także zbytu ww. nawozu w zredukowanej cenie (2\%) oraz uśredniając podane zakresy wydajności, otrzymamy miesięcznie dochód w granicach od 15120 zł do 40280 zł.

Należy podkreślić, że końcowy zysk z wydobycia osadu dennego i przekształcenia go w nawóz zostanie pomniejszony o pokrycie kosztów uzyskania certyfikatu na jego sprzedaż oraz o wydatki organizacyjne.

\section{Podsumowanie}

Opłacalność zastosowania oferowanej technologii ujawni się dopiero wówczas, kiedy będziemy mogli przetwarzać wydobyte osady denne na wieloskładnikowe nawozy o cechach umożliwiających konkurencyjność na rynku lub też zastosujemy wspomnianą technologię rozprowadzania osadów dennych bezpośrednio po lub pod powierzchnią gleby na polach.

\section{Wnioski}

1. Opisana technologia dzięki kompleksowemu ujęciu stwarza możliwości zmniejszenia kosztów rewitalizacji, a zarazem dostosowania małych zbiorników wodnych do spełniania nowych funkcji, jak rekreacja, magazynowanie wody itp. Podjęcie decyzji o rewitalizacji wymaga opracowania szczegółowego planu jej realizacji z uwzględnieniem obowiązujących przepisów.

2. Wprowadzenie opisywanej rewitalizacji do działań przy aktualizacji planu zagospodarowania Mazowsza może w końcowym efekcie przynieść korzyści miejscowym samorządom. 


\section{Bibliografia}

Bednarczyk T., Madeyski M., 1990, Wstępna ocena ilości doprowadzonych namułów do stawów o zróżnicowanym zasilaniu, "Zeszyty Naukowe Akademii Rolniczej we Wrocławiu. Melioracja”, 34, s. 83-92.

Bednarczyk T., Madeyski M., 1992, Czynniki wptywające na intensywność zamulania stawów rybnych, „Zeszyty Naukowe Akademii Rolniczej we Wrocławiu. Melioracja”, 40, s. 87-100.

Bednarczyk T., Madeyski M., 2002, Określenie ciężaru objętościowego osadów dennych stawów rybnych, "Zeszyty Naukowe Akademii Rolniczej w Krakowie. Inżynieria Środowiska”, 23, s. 301-306.

Bednarz T., Starzecka A., Mazurkiewicz-Broń G., 2002, Procesy mikrobiologiczne towarzyszące glonowym i sinicowym zakwitom wody, „Wiadomości botaniczne”, 46, 1-2, s. 45-55.

Brogowski Z., Czerwiński Z., 1986, Materiały do ćwiczeń z gleboznawstwa, cz. 2. Ćwiczenia laboratoryjne, wyd. 5., SGGW, Warszawa.

Eymontt A., Wierzbicki K., 2013, Nowa technologia usuwania antropogenicznych osadów dennych, „Problemy Inżynierii Rolniczej”, 4, 82, s. 129-138.

Eymontt A., Wierzbicki K., 2015, Analiza i ocena możliwości wydobywania antropogenicznych osadów dennych z jezior, zbiorników i cieków wodnych, „Wiadomości Melioracyjne i Łąkarskie”, 3, 446, s. 113-120.

Eymontt A. i in., 2017, Eymontt A., Wierzbicki K., Zygmunt Z., Burzyńska I., Rossa L., Nowa technologia wydobywania osadów dennych z rowów na stawach rybnych $i$ ich zastosowanie w rolnictwie, „Komunikaty Rybackie”, 2.

Gałka B., Witkowski M., 2010, Charakterystyka osadów dennych zbiornika zaporowego Młyny oraz możliwości rolniczego ich wykorzystania, „Woda - Środowisko - Obszary Wiejskie” t. 10, 4, 32, s. 53-63.

Komornicki T. i in., 2012, Komornicki T., Bański J., Śleszyński P., Rosik P., Czapiewski K.Ł., Korcelli P., Świątek D., Degórska B., Siłka P., Wiśniewski R., Stępniak M., Mazur M., Zagospodarowanie infrastrukturalne $i$ kapitał fizyczny oraz policentryczność rozwoju Mazowsza, TRENDY ROZWOJOWE MAZOWSZA, 4, MBPR, Warszawa.

Kostecki M., 2014, Rekultywacja antropogenicznego zbiornika wodnego Pławniowice metoda usuwania hipolimnionu - studium limnologiczne, „Prace i studia”, Instytut Podstaw Inżynierii Środowiska PAN, Zabrze.

Leszczyński M., Kadłubowski J., 2016, Ustawa o Rewitalizacji. Praktyczny komentarz, Ministerstwo Infrastruktury i Budownictwa, Departament Polityki Przestrzennej, Warszawa.

Madeyski M., 1999, Charakterystyka reologiczna osadów stawowych, „Zeszyty Naukowe Akademii Rolniczej w Krakowie. Inżynieria Środowiska", 19, s. 37-47. 
Madeyski M., 2002, Sedymentacja osadów stawowych, "Zeszyty Naukowe Akademii Rolniczej w Krakowie. Inżynieria Środowiska”, 23, s. 267-273.

Madeyski M., 2003a, Możliwości usunięcia osadów z dna stawów i zbiorników, „Zeszyty Naukowe Akademii Rolniczej w Krakowie. Inżynieria Środowiska", 24, s. 89-96.

Madeyski M., 2003b, Ogólnopolska Konferencja Naukowa: Małe zbiorniki wodne i stawy rybne w środowisku przyrodniczym, „Wiadomości Melioracyjne i Łąkarskie”, 1, 46, s. 49-50.

Madeyski M., 2003c, Zamulanie stawów rybnych, „Wiadomości Melioracyjne i Łąkarskie”, 3, 46, s. $121-122$.

Parzonka W., 1961, Ruch rozwodnionego mułu w przewodach zamkniętych, "Zeszyty Naukowe Wyższej Szkoły Rolniczej”: Referaty z sesji naukowej Wydziału Melioracji Wodnych, listopad, Wrocław, s. 33-41.

Parzonka W., 1977, Hydrauliczne podstawy transportu rurowego mieszanin dwufazowych, skrypt AR, Wrocław.

Sałański T., 2012, Zadania do realizacji przez samorzady na Mazowszu, TRENDY ROZWOJOWE MAZOWSZA, 1, MBPR, Warszawa.

Sałański T., 2014, Potencjały rozwojowe i zarządzanie strategiczne w gminach Mazowsza. Raport $z$ wyników badania IDI w samorządach gminnych województwa mazowieckiego, TRENDY ROZWOJOWE MAZOWSZA, 14, MBPR, Warszawa.

Sikorska P., 2016, O rewitalizacji na Mazowszu, „MAZOWSZE Studia Regionalne”, 19, s. 249-258.

Siuda W., Chróst R.J., 2015, Hydrobiotechnologia - biologiczne podstawy, aktualny stan wiedzy i perspektywy rozwoju, „Technologia wody”, 5, 43, s. 31-41.

Siwek H., Włodarczyk M., 2013, Charakterystyka struktury powierzchni osadów dennych w małych polimiktycznych zbiornikach wodnych, "Przemysł Chemiczny”, 7, 97, s. 1272-1275.

Stręk F., 1981, Mieszanie i mieszalniki, Wydawnictwo Naukowo-Techniczne, Warszawa.

Strzelczyk M., Rossa L., 2016, Raport z badań przy zastosowaniu mikronizatu ze słomy, maszynopis ITP, Warszawa.

Wierzbicki K., 1982, Transport hydrauliczny w instalacjach rolniczego wykorzystania gnojowicy, Instytut Budownictwa, Elektryfikacji i Modernizacji Rolnictwa, Warszawa.

Zajkowski J., 2009, Efektywność systemów kanalizacyjnych na przykładzie Gminy Sokoły, praca doktorska, Warszawa.

\section{Akty prawne}

Dyrektywa Parlamentu Europejskiego i Rady 2013/39/UE z dnia 12 sierpnia 2013 r., https://circabc.europa.eu 
Rozporzadzenie Ministra Środowiska z dnia 9 września 2002 r. w sprawie standardów jakości gleby oraz standardów jakości ziemi, Dz.U. z 2002 r., nr 165, poz. 1359.

Rozporzadzenie Ministra Środowiska z dnia 16 kwietnia 2002 r. w sprawie rodzajów oraz stężeń substancji, które powoduja, że urobek jest zanieczyszczony, Dz.U z 2002 r., nr 55, poz. 498.

Uchwała nr 196/16 Sejmiku Województwa Mazowieckiego z dnia 21 listopada 2016 r. w sprawie przystapienia do sporzadzenia zmiany Planu Zagospodarowania Przestrzennego Województwa Mazowieckiego.

Ustawa z dnia 27 kwietnia 2001 r. Prawo ochrony środowiska, Dz.U. z 2017 r., poz. 519 z późn. zm. Ustawa z dnia 18 lipca 2001 r. Prawo wodne, Dz.U. z 2015 r., poz. 469.

Ustawa z dnia 13 kwietnia 2007 r. o zapobieganiu szkodom $w$ środowisku $i$ ich naprawie, Dz.U. z 2014 r., poz. 1789 z późn. zm.

Ustawa z dnia 9 października 2015 r. o rewitalizacji, Dz.U. z 2015 r., poz. 1777, t. 1.

\section{New opportunities for the revitalization of small bodies of water}

\section{ABSTRACT}

Significant advances in technology of extracting sediments from the bottom of water bodies and processing them into high-value organic fertilizers has created new opportunities for their reclamation. These new opportunities can be used advantageously when the Spatial Development Plan of Mazovia is updated, as well as in the implementation of Poland's commitments towards the European Union in the framework of the Water Framework Directive and the plans for waterway rehabilitation in Poland. This progress is manifested by the possibility of extracting bottom sediments with high concentrations of solid (about $30 \%$ ) of organic and mineral origin and having a low water content which is then sorbed by micronized biomass (e.g. straw) or rock (e.g. opoka) with bactericidal properties. Thanks to the developed comprehensive mining technology and subsequent processing of the aforementioned sediments for calibrated organic fertilizer, new possibilities for increasing the yield from light soils (about $60 \%$ in Poland), as well as reducing the cost of revitalization of small water reservoirs. Sediment extraction technology was developed and implemented at the Institute of Technology and Natural Sciences, based in Falenty together with firm Łukomet, thanks to co-financing from the European Regional Development Fund supervised by the Mazovian Unit for the Implementation of EU Projects.

\footnotetext{
dr hab. inż. Andrzej Eymontt, prof. nadzw. ITP, zajmuje się wodociagami i kanalizacja na terenach niezurbanizowanych oraz nowymi technologiami w produkcji rolniczej; autor kilkudziesięciu patentów i wzorów użytkowych oraz kilkuset artykułów i opracowań; kontakt: Instytut Technologiczno-Przyrodniczy w Falentach, Oddział w Warszawie, ul. Rakowiecka 32, 02-532 Warszawa, tel. 2254211 16, e-mail: a.eymontt@itp.edu.pl

prof. dr hab. inż. Krzysztof Wierzbicki, zajmuje się melioracją oraz wodociagami i kanalizacją na terenach wiejskich oraz nowymi technologiami w produkcji zwierzęcej i roślinnej; autor kilkudziesięciu patentów $i$ wzorów użytkowych oraz kilkuset artykułów $i$ opracowań w tych dziedzinach; kontakt: Instytut Technologiczno-Przyrodniczy w Falentach, Oddziat w Warszawie, ul. Rakowiecka 32, 02-532 Warszawa, tel. 2254211 18, e-mail: k.wierzbicki@itp.edu.pl
} 